\title{
Growth Response of Oreochromis niloticus Fingerlings to Sun-dried Maggot Substituted Diets
}

\author{
MUSTAPHA, Abdur-Rahman Kolawole Ph.D
}

\begin{abstract}
The study was designed to investigate the value of sundried housefly maggot diet as protein source and the level of inclusion for optimum growth in the diet of Oreochromis niloticus fingerlings. Five experimental diets, four fresh maggot substituted diets containing $25 \%, 50 \%, 75 \%$ and $100 \%$ sundried maggot meal and a control ( $0 \%$ maggot inclusion) were prepared and tested on triplicate groups of $O$. niloticus fingerlings ( mean weight of $0.52 \mathrm{~g}$ ) for twelve weeks. The fish were fed twice daily at $3 \%$ of their body weight. Water quality parameters showed that maggot did not pollute the water media. The best growth rate was recorded among the fish fed control diet and 50\% sundried maggot inclusion as the only protein source and the least growth rate was showed by fingerlings fed $100 \%$ sundried $h$ maggot inclusion. Analyses of Specific Growth Rate, Feed Conversion Ratio and Protein Efficiency Ratio showed that there was no significant difference in weight gained by the fish fed the five diets except $100 \%$ sundried maggot substituted diet. The study indicated that sundried maggot meal can be successfully used to replace fishmeal partially or completely from $25 \%$ up to $75 \%$ in the diet of $O$. niloticus fingerlings for optimal growth and nutrient utilization. Based on these results, maggot meal is suggested as an effective and sustainable protein source to replace fishmeal in the diet of farmed tilapia.
\end{abstract}

Keywords - Fishmeal, Housefly maggot, Optimum growth, Diet, Weight gained, Specific Growth Rate.

\section{INTRODUCTION}

Population growth has been much faster than that of food production in most of the tropical countries, resulting in food shortages and malnutrition. Per capital supply of total protein in the developing countries is about $5 \%$ of that in the developed countries, while animal protein supply in the developing countries account for only $22 \%$ of that in the developed countries (Shang, 1996).

Aquaculture is an example of an industry that is rapidly developing on a global basis. The industry has tradition spanning over 2000 years. New technologies have made rapid increase possible during the last decades, especially developing countries. However, there are several examples showing that some formerly unpredictable problems might arise, causing problems both for the industry and the environment. A faster

MUSTAPHA, Abdur-Rahman Kolawole Ph.D, Department of Biology, Osun State College of Education, Ila Orangun, Osun state, Nigeria. goal should be to combine traditional and new technology to ensure sustained development. The potential of fish production through aquaculture is now realize; because it is obvious that our fish requirement cannot be met from capture fishers alone. FAO (2000) note that during the past three decades aquaculture has become the fastest growing food production sector and it is increasing important contributor to natural economic development in terms of global food supply and food security. Fish production has a special role in enhancing food security and in alleviation poverty as fish is highly nutritious food that forms the essential part of the diet large proportion of the people in developing countries

Fish is considered nutritional equivalent to meal in protein high in essential minerals and low in saturated fats in instance. It is an important component of total human food consumption and a principal source of animal protein for more than half of the world population. Globally, fish contributes about $17 \%$ of animal protein supply, but in many countries people derive as high as 50\%, or more of their daily animal protein requirement from fish (e.g. Bangladesh, Indondesia, Japan, Philippines, Sierra Leone, Thailand e.t.c). FAO (2000). The limited water resources and predicted shortage of animal protein in Nigeria necessitate the evaluation of all means of multiple water use and unconventional method of animal production as wastewater aquaculture.

Several factors militate against the effort being made to develop fish to increase fish supply through fish farming. Outstanding among these are scarcity and high cost of fishmeal. These factors reduce profit and discourage many would be farmers. According to Adesulu and Mustapha, (2002), the major constraint to rapid development of aquaculture in Nigeria is the inadequate supply of feedstuff at economic prices. Life stock depends on and competes with human for the available cereal. Legumes and protein concentrates thereby worsen in their scarcity. This scarcity is responsible for the high price of finished feeds. This high cost of finished feed reduces profit and consequently discourages investment on the large-scale expansion of aquaculture. This development has promoted fish culturist in Nigeria to start a deeper search into the environment to source for a low cost alternative to these expensive ingredients in the diet of fish. The increase cost of fish diet is increasing daily not because of inflation but because most of the feedstuff used in preparing fish diet faces serious competition 
from an as food and some of such feedstuff include soyabeans, maize, sorghum and groundnut.

In order to continue the rapid pace of expansion, industry must look to new development and technologies such as feed cost and formulation. Efforts are on to replace the fishmeal as ingredient of fish feed with less expensive product of good quality protein that can eventually, lead to towards using by-products and waste products that are regarded as useless/ordinary and are not directly used by human. Various studies have been conducted with sustainable alternative protein sources to determine their effects on fish growth (Emilie et al., 2017; Cabral et al., 2011; Silva et al., 2010). Alternative protein sources like cottonseed meal, parkia seed and blood meal (Olaleye, 1991), Sorghum offal (Adikwe and Hamisu, 1995) soya bean meal (Eyo, 2005), rubber seed meal (Eyo and Ezechie, 2004), feather meal (Vincent et al, 2014) and earthworm meal (Johannes et al'., 2014) have been tried. In the same vane Fagbenro (1996) reported that an alternative would be the use of available good quality and relatively inexpensive non-conventional feedstuff for feed formation.

Efforts are on to go into the use and alternative low cost and locally available plant and animal protein source to replace or partially substitute of portion of the fishmeal. Maggots have only been associated with waste product with decay worthless in Nigeria Now maggot has come to be known not only as safe food for fishes but also as rich protein source for them (Adesulu and Mustapha, 2002). Maggot is one of the alternatives of protein that are being evaluated or have potential as partial or whole replacement for fishmeal in agricultural diets (Spinelli, 1978). Its explosion as source of edible protein has received little attention in the country. Maggots are rich in phosphorus, trace elements and vitamin B complex (Teotia and Miller, 1994). The value of crude protein from maggot reported by various researches is as follows: Ajayi (1997), 48.8\% crude protein, Adesulu and Mustapha (2000), 42.2\% crude protein and Spinells (1978) 45\% crude oil. Maggots have only been associated with waste product, decay and worthlessness in Nigeria. Insect-based diets have been recognized and studied in recent times as one of the cheaper alternatives to fishmeal. Insects such as the black soldier fly (Hermetia illucens), the mealworm beetle (Tenebrio molitor) and the house fly (Musca domestica) have been studied as alternative protein sources and as substitute for fish meal in fish diets with promising results (Emilie et al., 2017; Ogunji et al., 2008; Zuidhof et al., 2003; $\mathrm{Ng}$ et al., 2001;). Interestingly maggot supplemented meal have been used successfully to feed Oreochromis niloticus fingerlings (Emilie et al., 2017; Ezewudo et al., 2015; Ajani et al., 2004; Idowu et al., 2003; Fasakin et al., 2003; Akinwande et al., 2002; Adesulu and Mustapha, 2000; Faturoti et al., 1995). Housefly (Musca domestica) maggot meal was reported to contain 39-65\% protein (Awoniyi et al., 2003; Atteh and Ologbenla, 1993), while the protein content of Chrysomya megacephala maggot meal ranged from 52-56\% depending on the age of maggots at harvesting. Such variations in protein content could be attributed to the processing, drying, storage and protein estimation methods employed, or the substrate used for the production of housefly maggots (Ogunji et al., 2008; Awoniyi et al., 2003). Maggot has come to be known not only as safe food for fishes, but also as rich protein source for them. Maggots are produced from the semi transparent larval stage of the housefly, Musca domestica and are used to process magmeal. Studies have shown that magmeal is of high biological value. The percentage of crude protein of housefly maggot ranges from $39-61.4 \%$, lipid $12.5-21 \%$, and crude fiber $5.8-8.2 \%$. Examination of the comparative minerals and amino acid contents of fishmeal and maggot meal showed that no essential amino acid was limiting (Adesulu and Mustapha, 2000). Spinelli J, (1978) used magmeal protein in the diets of rainbow trout. The protein provided growth and feed conversion levels equivalent to fish meal at substitution levels ranging from 25-100 \%. Fashina-Bombata and Balogun (1997) and Ajani et al., (2004) reported that magmeal can replace up to 100 percent of fish meal in the diets of Nile tilapia (O. niloticus).

The high demand of $O$. niloticus has prompted countries such as China, Malaysia, Brazil, Thailand and the Philippines to invest in tilapia culture (Sing et al., 2014; Watanabe et al., 2002), which in turn has elevated tilapia to second place amongst the farm-raised food fish in the world by volume (FAO, 2011).This present study was carried out to determine the best level of replacement of fishmeal with maggot meal in the diet of O. niloticus fingerlings.

\section{MATERIALS AND METHODS}

\section{A. Collection of Maggot}

Maggots used was those of housefly (Musca domestica). The poultry dropping were collected from the part where maggots were highly concentrated into a 50 litres bowl until it was filled up. The bowl was left for few hours to allow the maggots to move to the bottom of the bowl. The maggots moved away from the upper surface and congregated at the bottom of the bowl. The method gives room for collection of live maggots and dead maggots and pupas are discarded with other waste. Further separation was done by sieving and freeing them from waste particles. The maggots were thoroughly washed until they showed their characteristics whitish colour. They were killed by subjecting them to low temperature at 50C and were kept in the refrigerator for further use.

\section{B. Source of other feedstuff}

Starch, minerals and vitamin premix were obtained from a livestock feed store and yellow maize were obtained from the local market. The fish used for the fishmeal were freshly caught from pond.

\section{Feedstuff Preparation}

The sun dried maggots and yellow maize were milled separated using a grinding machine, packed separately and stored for use. The fish after being degutted and discaled was boiled for ten minutes and then pressed to remove the water and oil. It was dried in the oven at $95 \%{ }^{\circ} \mathrm{C}$ for 12 hours and then 
milled and packed for use. The various ingredients were weighed and thoroughly mixed together. It was wet mixed with water of $50^{\circ} \mathrm{C}$. The mixture was pelleted and sun-dried. It was then packed and dispensed as required.

\section{Feed Formulation}

Pearson Square Method described by Pulin and Jhingran (1984) was use to formulate a $35 \%$ crude protein diet for the fingerlings. Prior to formulation of the experimental diets, the proximate nutrient composition of fishmeal and maggot meal was determined using (AOAC, 2012) method. Five diets with increasing levels of substitution of fishmeal by maggot meal D1 (25\%), $\mathrm{D}_{2}(50 \%), \mathrm{D} 3(75 \%), \mathrm{D}_{4}(100 \%)$ and $\mathrm{D}_{5}(0 \%)$ maggot meal in the protein fraction were prepared. The diet containing fishmeal as the only protein source ( $0 \%$ maggot inclusion) was taken as control (Table 1). Proximate analysis was carried out to determine the moisture content, ash and crude protein of the five diets (AOAC, 2012). Growth indices were determined to properly evaluate the performance of the fingerlings in the experimental diets.

\section{E. Experimental Set-up}

The experiments were carried out in 15 plastic bowls (240 litre each) in the aquaculture centre laboratory at Obafemi Awolowo University, Ile-Ife. Each bowl was filled with filtered water from Opa dam up to three-quarter of the volume. 300 fingerlings of Oreochromis niloticus with a mean weight of 0.52 \pm 0.062 were acclimatized in the laboratory for one week. The survivors after one week were weighed and randomly assigned to the bowls at a stocking density of 20 fingerlings per bowl. Feeding commenced 48 hours after stocking, so as to ensure that all the stocked fish empty their gastro-intestinal tract. Each diet treatment was given in triplicates. Fish were kept in a natural photoperiod regime and the water temperature was $25 \pm 1.8^{\circ} \mathrm{C}$. The fish were fed for 12 weeks at $3 \%$ body weight with their respective test diet twice daily. The entire population of each bowl was weighed bi-weekly and the feeding rate adjusted according to the mean fish weight in each tank. The bowls were monitored daily and dead fish number in each bowl was recorded and percentage survival was estimated. Water quality is controlled by replacing the water loss by evaporation, daily cleaning, changing the water weekly and removal of uneaten food. Water temperature, $\mathrm{pH}$ and dissolved oxygen were monitored weekly using standard method (APHA, 1985). At the end of the feeding trial, fish were fasted for $24 \mathrm{~h}$ before the final body weight was recorded.

Specific Growth Rate (SGR), Feed Conversion Ratio (FCR) and Protein Efficiency Ratio (PER) were calculated according to the method of Olvera- Novoa et al., (1990), Eyo ( 2005) ,Olaniyi and Salau (2013) as follows:

TABLE I: MINERALS CONTENTS OF MAGGOT AND FISH MEAL

\begin{tabular}{|l|l|l|l|l|l|l|l|l|l|}
\hline & $\mathrm{Ca}(\%)$ & $\mathrm{Mg}(\%)$ & $\mathrm{Na}(\%)$ & $\mathrm{K}(\%)$ & $\mathrm{Fe}(\mathrm{ppm})$ & $\mathrm{Zn}(\mathrm{ppm})$ & $\mathrm{Cu}(\mathrm{ppm})$ & $\mathrm{Mn}(\mathrm{ppm})$ & $\mathrm{Pb}(\mathrm{ppm})$ \\
\hline Fish meal & $0 . .40$ & 0.02 & 0.55 & 0.08 & 162 & 173 & - & 86 & - \\
\hline Maggot & 0.36 & 0.21 & 0.31 & 0.45 & 1129 & 49.63 & 21.47 & 15.41 & 1.08 \\
\hline
\end{tabular}

Adesulu and Mustapha (2000)
$\mathrm{SGR}=\mathrm{W}_{1}-\mathrm{Wo}_{\mathrm{t}} \mathrm{X} 100$ (where $\mathrm{W}_{1}=$ final weight, $\mathrm{Wo}_{\mathrm{o}}=$ initial weight, $\mathrm{t}=$ time in days).

FCR $=$ Total feed given/Weight gained

$\mathrm{PER}=$ Weight gain/Protein fed

Where protein $\mathrm{fed}=\%$ protein in diet $\mathrm{x}$ total diet consumed $/ 100$

\section{DATA ANALYSIS}

Growth performance and nutrients utilization were evaluated from data on weight gain, SGR, FCR, PER and Carcass composition. The data were analysed using One-way analysis of Variance (ANOVA) test followed by the least significant (LSD) test for comparison among treatment mean of $5 \%$ probability $(\mathrm{P}$ $=0.05)$.

\section{RESUlTS AND DISCUSSION}

The physico-chemical parameters of the culture media were found suitable for fish. The water temperature range of 26.01 to $27.52^{\circ} \mathrm{C}$ was within the range described by Okayi (2003) for river Benue and, Komolafe and Arawomo (2008) for Osinmo reservoir. The $\mathrm{pH}$ range of 7.40 to 7.60 were within the range of 7 - 7.69 recommended for Tilapia culture (Burn and Stickney, 1980) and the range of 6.6 and 8.5 known for most streams and lakes of the world (Boyd, 1979).

Oxygen concentration were found to reduce with time in the culture medium with the value ranging from $4.10 \mathrm{ml} / \mathrm{g}$ to $5.50 \mathrm{mg} / \mathrm{l}$. Dissolved oxygen range of $1 \mathrm{ml} / \mathrm{g}$ to $4.99 \mathrm{mg} / \mathrm{l}$ make fish survive, but slows the growth on prolonged exposure of the fish to the condition and the value is within tolerance limits for tilapia (El-Sayed, 2006; Beveridge and McAndrew, 2000). High survival of fish was consequent of water quality parameter being within the optimum range for the fish. Oreochromis niloticus like other cichlids is highly adaptable and can tolerate adverse condition within their habitat. The mortality, though very insignificant was attributed to stress encountered during frequent sampling and faeces collection .

Proximate and amino acid analyses of the maggot meal and test diets were carried out. Minerals and amino acids contents of Maggot and Fish meal are shown in Tables I, II(a and b) respectively. The composition of the experimental diets and the proximate analysis of the diets including calorimetric energy termination are shown in Table III and IV respectively. 
TABLE IIA : AMINO ACID CONTENTS OF MAGGOT AND FISH MEAL

\begin{tabular}{|l|l|l|l|l|l|l|l|l|l|}
\hline & Alanine & Arginine & asparagine & cysteine & Glutamine & glycine & Histidine & isoleucine & leucine \\
\hline Fishmeal & 6.34 & 5.82 & 9.32 & 0.70 & 13.30 & 5.90 & 2.22 & 4.36 & 7.35 \\
\hline Maggot & 6.15 & 5.42 & 10.80 & 0.80 & 12.20 & 5.40 & 3.50 & 4.13 & 6.95 \\
\hline
\end{tabular}

Adesulu and Mustapha (2000)

TABLE IIB : AMINO ACID CONTENTS OF MAGGOT AND FISH MEAL

\begin{tabular}{|l|l|l|l|l|l|l|l|l|l|}
\hline & Lysine & Methionine & Pheny-lalanine & Proline & Serine & Threonine & Trypto-phan & tyrosine & valine \\
\hline Fish meal & 7.85 & 2.84 & 4.35 & 4.35 & 4.55 & 4.55 & 1.33 & 3.45 & 5.65 \\
\hline Maggot & 7.37 & 2.24 & 6.95 & 3.66 & 4.51 & 4.53 & 1.45 & 8.10 & 5.60 \\
\hline
\end{tabular}

Adesulu and Mustapha (2000).

TABLE III: COMPOSITION OF EXPERIMENTAL DIETS (DRY WEIGHT)

\begin{tabular}{|l|l|l|l|l|l|}
\hline Feedstuff & $\mathbf{D t}_{\mathbf{1}}$ & $\mathbf{D t}_{\mathbf{2}}$ & $\mathbf{D t}_{\mathbf{3}}$ & $\mathbf{D}_{\mathbf{4}}$ & $\mathbf{D t}_{\mathbf{5}}$ \\
\hline Fish meal & 28.63 & 19.085 & 9.54 & & 38.17 \\
\hline Maggot & 9.54 & 19.085 & 28.63 & 38.17 & - \\
\hline Yellow Maize & 56.83 & 56.83 & 56.83 & 56,83 & 56.83 \\
\hline Vit. Premix & 2.00 & 2.00 & 2.00 & 2.00 & 2.00 \\
\hline Palm oil & 0.50 & 0.50 & 0.50 & 0.50 & 0.50 \\
\hline Salt(NaCl) & 0.50 & 0.50 & 0.50 & 0.50 & 0.50 \\
\hline Starch (Binder) & 2.00 & 2.00 & 2.00 & 2.00 & 2.00 \\
\hline Total & $\mathbf{1 0 0}$ & $\mathbf{1 0 0}$ & $\mathbf{1 0 0}$ & $\mathbf{1 0 0}$ & $\mathbf{1 0 0}$ \\
\hline
\end{tabular}

TABLE IV: PROXIMATE COMPOSITION OF THE EXPERIMENT DIET (\% WEIGHT)

\begin{tabular}{|l|l|l|l|l|l|}
\hline Feedstuff & $\mathbf{D t}_{\mathbf{1}}$ & $\mathbf{D t}_{\mathbf{2}}$ & $\mathbf{D t}_{\mathbf{3}}$ & $\mathbf{D}_{\mathbf{4}}$ & $\mathbf{D t}_{\mathbf{5}}$ \\
\hline Moisture & 6.90 & 6.82 & 6.08 & 5.95 & 8.90 \\
\hline Protein & 35.60 & 35.40 & 35.01 & 36.20 & 36.67 \\
\hline Ether extract & 9.82 & 10.02 & 11.08 & 15.80 & 10.28 \\
\hline Crude oil & 3.86 & 6.13 & 5.80 & 7.10 & 7.34 \\
\hline Ash & 7.65 & 12.22 & 11.02 & 11.80 & 5.77 \\
\hline NFE & 36.71 & 29.41 & 31.01 & 23.75 & 43.04 \\
\hline Energy Kcal/kg & 4764 & 4764 & 4708 & 4695 & 4562.5 \\
\hline
\end{tabular}

*Values are mean of three replicates

Bi-weekly weight gain by the fish fingerlings fed the experimental diets is shown in Table $\mathrm{V}$ and figures (1a, 1b and 1c). Table VI, VII and VIII show the growth performance parameters, initial and final carcass composition of the fish and records of water quality parameters respectively.

TABLE V: BI-WEEKLY GROWTH RECORD OF THE FINGERLING FED FOR 12 WEEKS

\begin{tabular}{|l|l|l|l|l|l|}
\hline Week & $\mathbf{D t}_{\mathbf{1}}$ & $\mathbf{D t}_{\mathbf{2}}$ & $\mathbf{D t}_{\mathbf{3}}$ & $\mathbf{D}_{\mathbf{4}}$ & $\mathbf{D t}_{\mathbf{5}}$ \\
\hline 0 & 0.52 & 0.53 & 0.54 & 0.51 & 0.53 \\
\hline 2 & 0.62 & 0.67 & 0.66 & 0.64 & 0.63 \\
\hline 4 & 0.86 & 0.91 & 0.80 & 0.76 & 0.93 \\
\hline 6 & 1.22 & 1.31 & 1.22 & 0.09 & 1.36 \\
\hline 8 & 1.60 & 1.79 & 1.62 & 1.13 & 1.82 \\
\hline 10 & 2.15 & 2.00 & 1.62 & 1.31 & 2.19 \\
\hline 12 & 2.18 & 2.50 & 2.24 & 1.51 & 2.55 \\
\hline Mean Weight Gain & 1.66 & 1.97 & 1.70 & 0.98 & 2.02 \\
\hline
\end{tabular}

$* *$ Values are mean of three replicates 


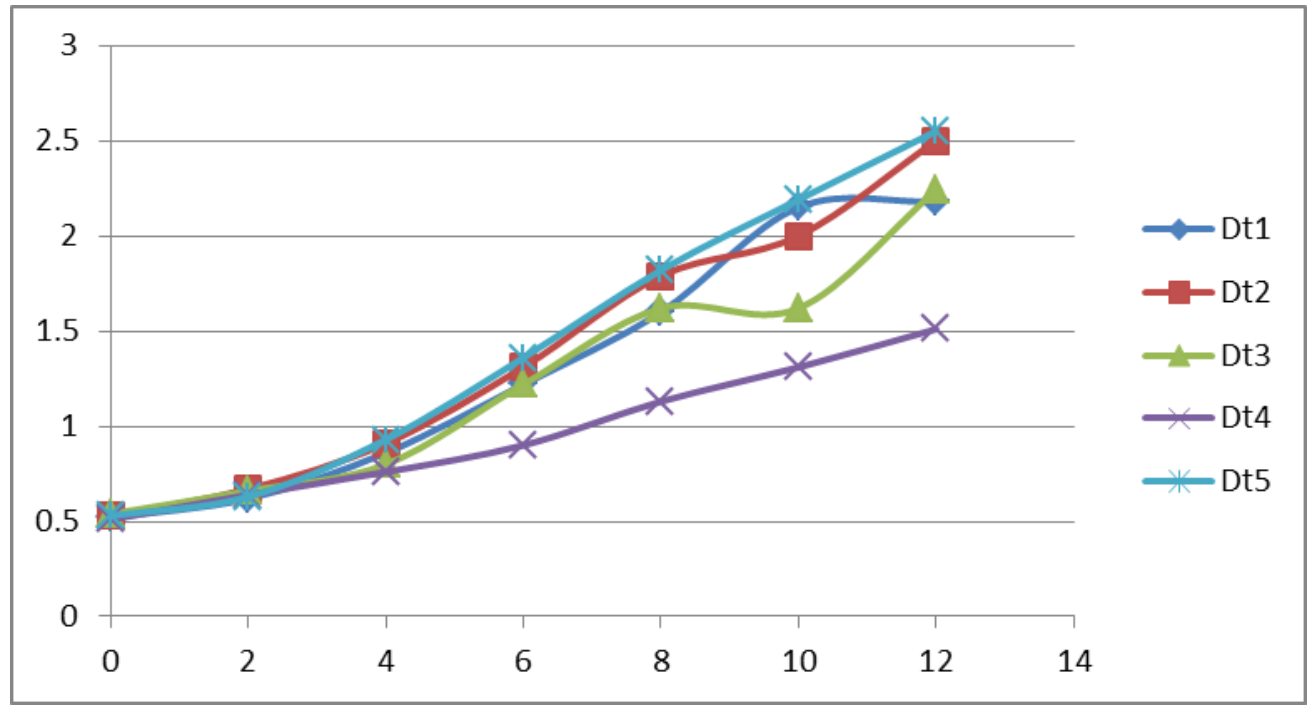

Fig. 1a: Growth performance of O. niloticus fingerlings fed diet of different protein levels of maggots for 12 weeks.

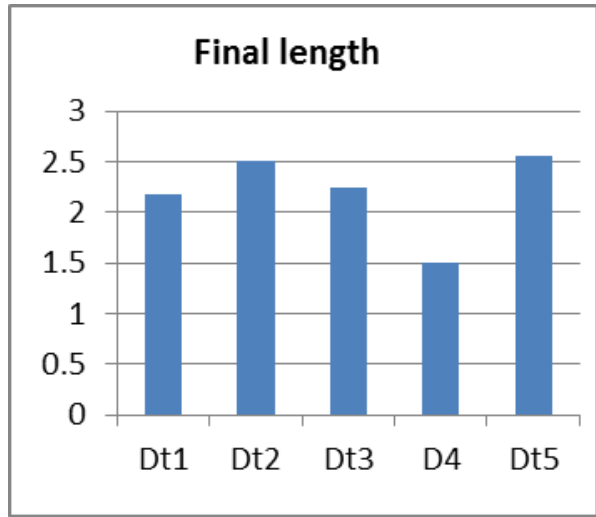

Fig2a

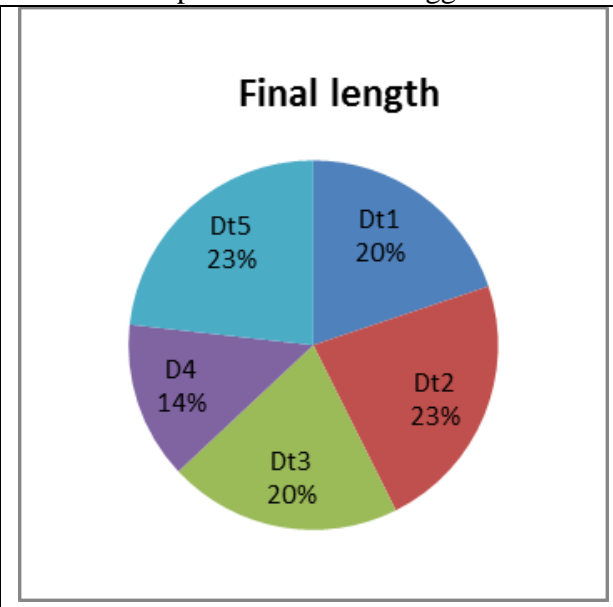

Fig2b

Figure 2(a and b): Bi-weekly records of weight increment $(\mathrm{g})$ of Oreochromis niloticus fingerlings fed for12 weeks.

TABLE VI: GROWTH PERFORMANCE OF OREOCHROMIS NILOTICUS FINGERLINGS FED FOR 12 WEEKS

\begin{tabular}{|l|l|l|l|l|l|}
\hline & $\mathbf{D t}_{\mathbf{1}}$ & $\mathbf{D t}_{\mathbf{2}}$ & $\mathbf{D t}_{\mathbf{3}}$ & $\mathbf{D}_{\mathbf{4}}$ & $\mathbf{D t}_{\mathbf{5}}$ \\
\hline Initial mean weight & $0.52^{\mathrm{a}}$ & $0.53^{\mathrm{a}}$ & $0.54^{\mathrm{a}}$ & $0.53^{\mathrm{a}}$ & 0.53 \\
\hline final mean weight & $2.18^{\mathrm{a}}$ & $2.50^{\mathrm{a}}$ & $2.24^{\mathrm{ab}}$ & $1.15^{\mathrm{b}}$ & $2.55^{\mathrm{a}}$ \\
\hline Mean weight gain & $1.66^{\mathrm{ab}}$ & $1.97^{\mathrm{a}}$ & $1.70^{\mathrm{ab}}$ & $0.98^{\mathrm{b}}$ & $2.02^{\mathrm{a}}$ \\
\hline Specific growth rate & $1.71^{\mathrm{a}}$ & $1.85^{\mathrm{a}}$ & $1.69^{\mathrm{a}}$ & $1.25^{\mathrm{b}}$ & $1.87^{\mathrm{a}}$ \\
\hline Food conv. ratio & $102.0^{\mathrm{b}}$ & $94.2^{\mathrm{b}}$ & $102.3^{\mathrm{b}}$ & $135.5^{\mathrm{a}}$ & $93.1^{\mathrm{a}}$ \\
\hline Protein effic. ratio & $1.94^{\mathrm{a}}$ & $1.69^{\mathrm{a}}$ & $1.72^{\mathrm{ab}}$ & $2.10^{\mathrm{b}}$ & $1.61^{\mathrm{a}}$ \\
\hline \% survival & $98.3^{\mathrm{a}}$ & $98.3^{\mathrm{a}}$ & $100^{\mathrm{a}}$ & $93.3^{\mathrm{a}}$ & $96.07^{\mathrm{a}}$ \\
\hline
\end{tabular}

Figure in the same row having similar superscript are not

significantly different from one another $(\mathrm{p}>0.05)$ 


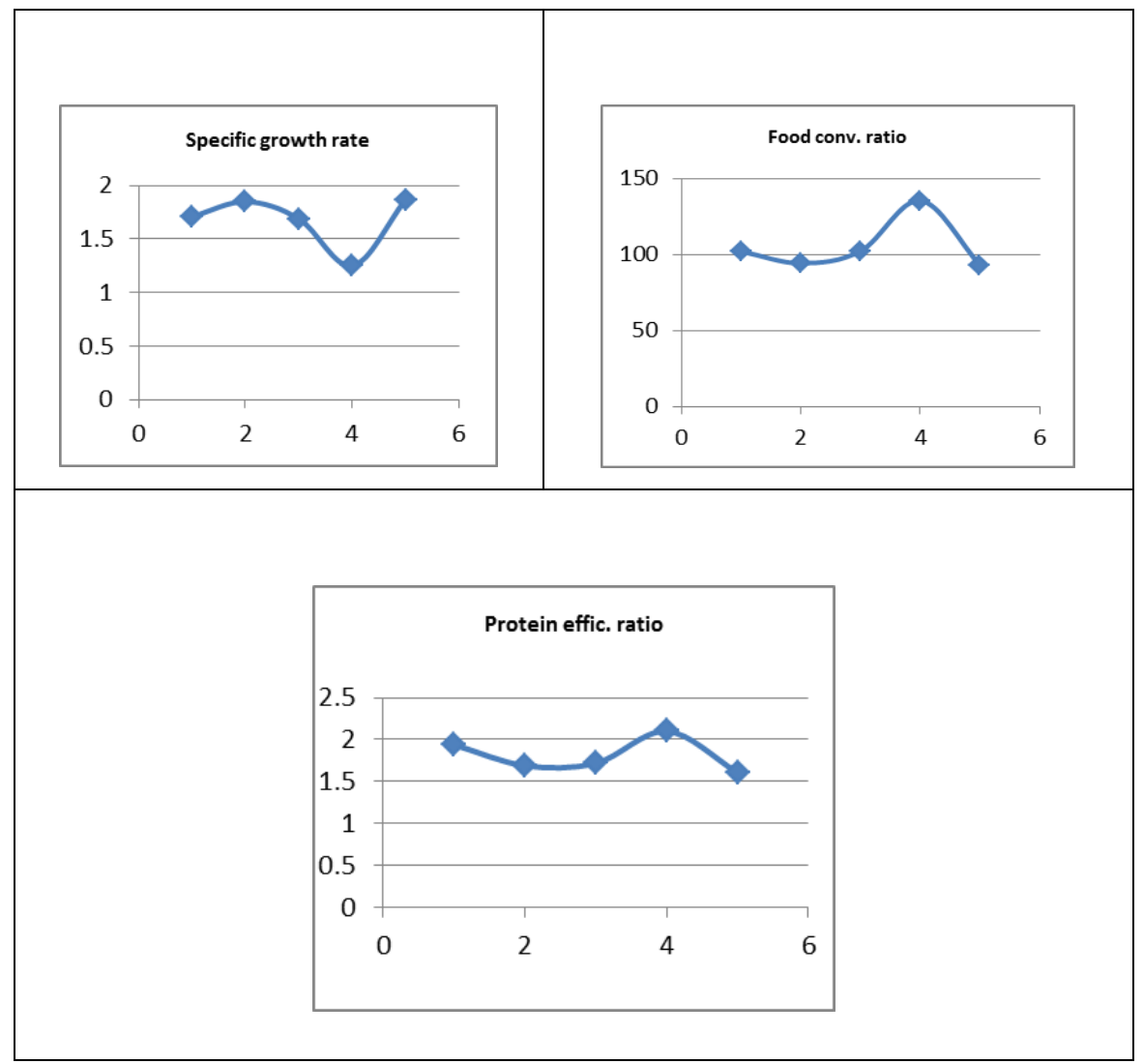

Figure 3: Relationship between specific growth rate, feed conversion ratio, protein efficiency ratio and dietary maggot inclusion levels

TABLE VII: INITIAL AND FINAL CARCASS COMPOSITION OF OREOCHROMIS NILOTICUS FED DIFFERENT PROTEIN OF MAGGOT DIETS

\begin{tabular}{|l|l|l|l|l|l|l|}
\hline Nutrients & & $\mathbf{D t}_{\mathbf{1}}$ & $\mathbf{D t}_{\mathbf{2}}$ & $\mathbf{D t}_{\mathbf{3}}$ & $\mathbf{D}_{\mathbf{4}}$ & $\mathbf{D t}_{\mathbf{5}}$ \\
\hline Protein (\%) & 19.42 & 22.6 & 23.3 & 22.2 & 20.9 & 23.8 \\
\hline Fat (\%) & 4.92 & 3.07 & 2.67 & 2.53 & 2.22 & 2.52 \\
\hline Crude fibre (\%) & $3.72^{\mathrm{a}}$ & $3.73^{\mathrm{a}}$ & $3.83^{\mathrm{a}}$ & $3.68^{\mathrm{a}}$ & $3.72^{\mathrm{a}}$ & $3.69^{\mathrm{a}}$ \\
\hline Ash (\%) & 3.72 & 3.73 & 3.83 & 3.68 & 3.72 & 3.69 \\
\hline Moisture (\%) & 2.95 & 2.87 & 3.10 & 2.91 & 3.13 & 3.22 \\
\hline
\end{tabular}

TABLE VIII: RECORDS OF WATER QUALITY PARAMETERS IN THE EXPERIMENTAL BOWLS

\begin{tabular}{|l|l|l|l|l|l|l|}
\hline $\begin{array}{l}\text { Physico-chemical } \\
\text { parameter }\end{array}$ & \multicolumn{5}{|c|}{ B (Sun-dried maggot diets) } & D Control Diet \\
\hline & Initial & Dt $_{\mathbf{1}}$ & $\mathbf{D t}_{\mathbf{2}}$ & $\mathbf{D t}_{\mathbf{3}}$ & $\mathbf{D}_{\mathbf{4}}$ & $\mathbf{D t}_{\mathbf{5}}$ \\
\hline Temp. $\left({ }^{\circ} \mathrm{C}\right)$ & 25.53 & 27.0 & 26.5 & 26.0 & 26.5 & 26.5 \\
\hline $\mathrm{pH}$ & 7.63 & 7.52 & 7.50 & 7.60 & 7.50 & 7.50 \\
\hline Dissolved oxygen & 7.55 & 5.30 & 5.42 & 5.03 & 2.90 & 5.59 \\
\hline
\end{tabular}

The best growth rate was recorded among fish fingerling fed with fishmeal as the only protein source $\left(D_{5}\right)$ while diet $\mathrm{D}_{4}$ (50 maggot meal) produced the second best growth response and nutrient. Diet $\mathrm{D}_{3}$ (75\% maggot inclusion) was the third best growth rate, the forth $\mathrm{D}_{1}$ (25\% maggot inclusion) and the least growth was shown by fingerling and feed diet containing $100 \%$ sun dried maggot meal as protein source $\left(\mathrm{D}_{4}\right)$. Weight gain were not significant different between 
treatments $(\mathrm{P}>0.05)$. The relationship between Specific Growth Rates (SGR) and protein dietary levels, Feed Conversion Ratio (FCR) and protein dietary levels, Protein Efficiency Ratio (PER) and protein dietary levels and are shown in Figure 3. SGR and FCR were not significantly different between the five treatments except those fed $\mathrm{D}_{4}$. The improvement in growth and feed efficiency recorded in Oreochromis niloticus fed maggot-supplemented diet suggest that maggot contain all the necessary growth promoting factors

According Agbede and Faleye (1998) feed ingredient of $20 \%$ protein level and above could be regarded as good protein source. There has been report that tilapia required relatively low protein (Nwadukwe, (1991). The protein efficiency ratio decreased as the maggot inclusion level increase. The phenomenon was similarly observed for that fish species, Sarotherodon mossambicus (Jauncey, 1982). The feed conversion ration and protein efficiency ratio in these studies were as good as maggot inclusion level below $40 \%$ for the diets. This favourably observed, despite provision of crude protein requirement in all the treatment shows that growth was influenced by both the quantity and quality of protein in diet. Amino acid profile and digestibility, energy content, environmental condition and nutritional history in different species of fish differ; as a result optimum protein level cannot be directly compared (Henken et al, 1986). In this work, it shows that the fish are capable of utilizing maggot-compounded diet at various substituted rate, but its best-feed conversion ratio was obtained at 50\% maggot inclusion level. The specific growth rate, feed conversion ratio and protein efficiency ratio values for the maggot diets indicated the acceptability of maggot diets to O. niloticus. The performance of fish fed on maggot supplement diet is attributed to its tender and easily digested nature. Tilapia requires relatively low protein level of about $25-30 \%$ as compared to the more carnivorous species (Nwadukwe, 1991). Crucially, the values for maggot meal are similar and can readily substitute locally produced fishmeal (Ezewudo et al., 2015; Henry et al., 2015; Barroso et al., 2014). Proximate analysis of fishmeal and housefly maggot meal suggested crude lipid was higher in maggot meal, a finding consistent with a previous study (Ogunji et al., 2008) where the nutrient composition of housefly maggot meal was evaluated.

The result of SGR indicated an increase in the weight gain and food utilization by the fish fingerling. The protein efficiency ratio, which decreased as the maggot inclusion level increase, was similar to the observance of Sarotherodon mossambicus (Jauncey, 1982). The value of FCR and PER becomes better as the protein level increased. This is favourably compared with those obtained by Faturoti et al., (1995) who found that fish fed $100 \%$ life poultry dung maggot had the highest percentage mean weight gain, SGR and lowest FCR than those artificial diets. O. niloticus fingerlings are capable of utilizing compounded diet effectively as shown by the low feed conversion ratio. The best-feed conversion ratio was obtained with 50\% sundried maggot diets. This is in contrast to Ezewudo et al., (2017), Olaniyi and Salau (2013) and Akinwande et al.,
(2002), who reported that fingerling performed better when fed with diet containing 75\% maggot protein inclusion level for fingerling of Oreochromis niloticus and Clarias gariepinus. In another research conducted by Mustapha (2001), the best growth rate was recorded among fingerling fed with diet containing $75 \%$ oven dried maggot meal, followed by $50 \%$ maggot inclusion and the least growth was exhibited by fingerlings fed diet containing $100 \%$ oven dried maggot meal as the protein source for Oreochromis niloticus.

The concentration of $\mathrm{K}, \mathrm{Ca}, \mathrm{Mg}, \mathrm{Na}, \mathrm{Fe}, \mathrm{Zn}$ analyzed for maggot meal were within the range of the value obtained for each of the element for Sarotherodon galilaeus by Olaleye and Akintunde (1991). This further confirms the suitability of maggot as Tilapia fishmeal. Spinelli (1978) had earlier shown that maggot contains the same number of amino acids found in fishmeal (including the ten essential ones for animals).This phenomenon is usually related to a deficiency or absence of one or more essential amino acids in those animal and plant protein sources. Moreover, insufficient amounts of certain essential amino acids in any given diet can cause fish to suffer cataracts (methionine and tryptophan) and scoliosis (tryptophan) (Cowey, 1994). High levels of fishmeal replacement with housefly maggot meal have been associated with low body weight gain in both fish and chickens (Ogunji et al., 2008; Oyelese, 2007). Earlier studies indicated that housefly maggot meal should only partially substitute fishmeal in the diets of omnivorous fish species such as catfish and Nile tilapia (Ogunji et al., 2008; Oyelese, 2007). Some authors reported replacement of fishmeal with housefly maggot meal at $50 \%$ or less provided the optimum level in chicken feed (Adeniji, 2007; Awoniyi et al., 2003). These earlier studies contrast with the present study which showed increased substitution of fishmeal by housefly maggot meal improved the growth, survival and feed efficiency of juvenile tilapia with the total replacement diet giving the optimal results. Although palatability of the maggot meal was not directly tested, these results and the observations in the laboratory indicated that there was no food rejection by the fish.

Housefly maggot meal contained all the essential amino acids needed by juvenile tilapia for normal growth and equivalent protein content to fishmeal. It is shown from this study that fresh maggot meal is favorable compared with fish meal in term of protein content and nutrient composition and has growth promoting ability. It is shown from this study that maggot's meal is favoured compare with fish meal in term of protein content and growth promoting ability. Fish diet containing 50\% crude protein of sun dried maggot is suitable for optimal growth and performances of Oreochromis niloticus and of showed a comparable weight gain, growth performance and feed efficiency to the control diet. There was no significant $p>0.05$ ) difference between them and the control diets. The result has shown that supplement of fish diet with a small amount of maggot meal can effectively promote growth of Oreochromis niloticus fingerlings. Fish diet containing 50\% fresh maggot in this work is most suitable for optimal growth and performances 
and it showed a comparable weight gain, growth performance and feed efficiency to the control diet. This was followed by Diet containing $75 \%$ maggot as crude protein. Low mortality and suitable water quality showed that fresh maggot diet did not pollute the water media. This study shows that sundried maggot meal can successfully be used to replace fishmeal in the diet of O.niloticus fingerlings and for optimum growth and nutrient utilization, $25 \%$ to $75 \%$ level of replacement of fishmeal with maggot meal is recommended. Housefly maggot larvae can be produced large quantity from agricultural waste. Therefore replacing of fishmeal with housefly maggot meal in $O$. niloticus feed would directly reduce the production costs.

\section{REFERENCES}

[1] Adesulu EA, Mustapha AK (2000). Use of housefly maggots as fish meal replacement in Tilapia culture: A recent vogue in Nigeria. In: K. Fitzsimmons, K., Filho, J.C. (Eds). Proceedings of 5 International Symposium on Tilapia in Aquaculture (ISTAV), Rio de Janeiro, Brazil. pp. 138-143.

[2] Adeniji AA (2007). Effect of replacing groundnut cake with maggot meal in the diet of broilers. Int J Poult Sci, 6: 822-825.

a. Adikwe IA , Hamisu A. (1995). Sorghum offal Tilapia (Oreochrimis niloticus) nutrition $9^{\text {th }}-10^{\text {th }}$ Annual Conference of Nigeria Association for Aquatic Science, University of Agriculture, Abeokuta, Programme and Book Abstract. Pp 18.

[3] Ajani EK, Nwanna LC, Musa BO (2004). Replacement of fishmeal with maggot meal in the diets of Nile tilapia, Oreochromis niloticus. World Aquaculture. 35: 52-54.

[4] Ajayi OO (1998). Evaluation of full fat of defaulted maggot meal in the nutrition of Clarias atropines M.Sc thesis, University of Technology, Akure, Nigeria.

[5] Akinwande AA, Ugwumba AAA, Ugwumba OA (2002). Effects of replacement of fish meal with maggot meal in the diet of Clarias gariepinus (Burchell, 1822) fingerlings. The Zoologist Vol. 1(2):41 - 46.

[6] Anyanwu, P.E. (1988). Water quality management in fish ponds. Being a lecture for participants at DFRRI/NIMOR organized aquaculture workshop at Ibadan, (Oyo State) and Abeokuta (Ogun State) $15^{\text {th }}-30^{\text {th }}$ June.

[7] AOAC. (Association of Official Analytical Chemists) International. (2012). Official Methods of Analysis of AOAC International, 19th Edition. Gaithersburg, Maryland, USA, AOAC International. 1230 Pp.

[8] APHA - AWWA - WPCF (1985). Standard Method for the examination of water and waste water $16^{\text {th }}$ Edition. Prepared jointly by the American Public Health Association, American water works association and water pollution control federation $1113 \mathrm{pp}$

[9] Atteh JO, Ologbenla S (1993). Replacement of fish meal with maggot in broiler diets: Effects on performance and nutrition. Niger JAnim Prod, 20: 44-49.

[10] Awoniyi T, Aletor V, Aina J (2003). Performance of broiler chickens fed on maggot meal in place of fishmeal. Int J Poult Sci,2: 271-274. https://doi.org/10.3923/ijps.2003.271.274

[11] Barroso FG, de Haro C, Sanchez-Muros MJ, Venegas E, Martinez-Sanchez A, Perez-Banon C, (2014). The potential of various insects species use as food for fish. Aquaculture , 422-423, https://doi.org/10.1016/j.aquaculture.2013.12.024

[12] Beveridge MCM, McAndrew BJ. (2000). Tilapias: Biology and Exploitation.Kluwer Academic Publishers193-201

[13] Boyd CE (1979). Water quality in warm water fish ponds. Agricultural Experiment station, Auburn University, Alabama, pp 358.

[14] Brugère C, Ridler N. (2004). Global aquaculture outlook in thenext decades: an analysis of national aquaculture production forecasts to 2030 . FAO Fisheries Circular No. 1001, Rome,FAO, 47p.

[15] Burns RG, Stickney, RR. (1980): Growth of Tilapia aurea in pond receiving poultry waste:Aquaculture, Amsterdam, Netherland 20:117 121 https://doi.org/10.1016/0044-8486(80)90040-X

[16] Cabral EM, Bacelar M, Batista S, Castro-Cunha M, Ozório ROA, Valente LMP, (2011). Replacement of fishmeal by increasing levels ofplant protein blends in diets for Senegalese sole (Soleasenegalensis) juveniles. Aquaculture, 322-323: 74-81.

https://doi.org/10.1016/j.aquaculture.2011.09.023

[17] Chakroff, M. (1978). Freshwater fish pond culture and management USA, Vita Publication Manual Series. 196pp

[18] Chow KW, (1978) Quality control in fish feed manufacturing in Fish Technology Aquaculture

[19] Development and Coordination Programme CADP/REP/80/11UNDP (385pp)

[20] Cowey CB, (1994). Amino acid requirements of fish: a critical appraisal of present values. Aquaculture, 124: 1-11. https://doi.org/10.1016/0044-8486(94)90349-2

[21] El-Sayed AFM. (2006). Tilapia Culture.wallingford, UK: CABI Publishing https://doi.org/10.1079/9780851990149.0000

[22] Emilie S, Will L, Francis J.M, David C. L (2017). Growth performance, feed utilization and body composition of advanced nursing Nile tilapia (Oreochromis niloticus) fed diets containing Black Soldier Fly (Hermetia illucens) laevae meal. Journal of Aquaculture Nutrition, 1-8.

[23] Eyo JE., (2005). Effects of substituting soya bean meal for maggot meal on acceptability of diets, Growth Performance and Cost benefits of diet fed to hybrid Catfish-Heterobranchus bidorsalis and Clarias gariepinus. Journal of Science and Technology Research, 4: 37-43.

[24] Eyo, JE. and Ezechie, CU (2004). The Effect of Rubber (Havea brasiliensis) seed meal based diets on diet acceptability and growth performance of Heterobranchus bidorsalis and Clarias gariepinus hybrid. Journal of Agricultural Research, 10: 20-25.

[25] Ezewudo BI., Monebi C. O, Ugwumba A. A.A. (2015). Production and utilization of Musca domestica maggots in the diet of Oreochromis niloticus (Linnaeus, 1758) fingerlings. African journal of agricultural research, 10(23): 2363- 2371 https://doi.org/10.5897/AJAR2014.9274

[26] FAO (2000). Aquaculture development beyond 2000: The Bangkok ration and strategy - Conference on Aquaculture Development in the third millennium, $20-25$ Feb. Bangkok, Thailand FAO Aquaculture news letter no. 25. The role of Aquaculture in word fisheries - Proceeding of the world fisheries congress. Theme 6: Edited by Tor. G. Heggberget Calcutta Oxford and IBH publishing co PVT Ltd. Pp.

[27] FAO (2011). Tilapia - February 2011. Available: http://www.globefish.org/tilapia-february-2011.html, Accessed 22 July 2012.

[28] Fagbenro, OA. (1996). Presence of potentials of Cocoa Pod Husk used in low-cost fish diet in Nigeria (pages 104 - 110), In the role of Aquaculture in word fisheries - Proceeding of the world fisheries congress. Theme 6 : Edited by Tor. G. Heggberget Calcutta Oxford and IBH publishing co PVT Ltd.

[29] Faturoti EO, Obasa SO, Bakare AL, (1995). Growth performance and nutrient utilization of Clarias gariepnus (Burchell 1822) fed live maggots Nigerian Association for Aquacultic Sciences. $9^{\text {th }} / 10^{\text {th }}$ Annual Conference Programme and Book of Abstract. Pp $14-15$

[30] Fasakin EA, Balogun AM, Ajayi OO, (2003). Evaluation of full fat and defatted maggot meals in the feeding of Clariid catfish Clarias gariepinus. Aquaculture Research. 34(9): 733-738. https://doi.org/10.1046/j.1365-2109.2003.00876.x

[31] Fashina-Bombata H .A and Balogun O, (1997). The effect of partial or total replacement of fish meal with maggot meal in the diet of tilapia (Oreochromis niloticus) fry. Journal of Prospects in Science 1: 178-181.

[32] Henken, AM., Machines MAM., Decker W. and Hogendoorn, H. (1986). The effect of dietary protein and energy content on growth rate and feed utilization of the African catfish, Clarias garienpinus (Burchell, 1982) Aquaculture 58: 55 - 74 https://doi.org/10.1016/0044-8486(86)90156-0

[33] Henry M, Gasco L, Piccolo G, Fountoulaki E (2015). Review on the use of insects in the diet of farmed fish: Past and future. Animal feed technology, 203, 1-22 https://doi.org/10.1016/j.anifeedsci.2015.03.001

[34] Hunner, J.V. and Dupree H.K. (1988). Pond Management. In Bait fish Culture Workshop Information Package (compiled by G.T. Bragger) Ontario Ministry of Natural Resources

[35] Huet, M. (1972). A textbook of fish culture. Breeding and cultivation of fish Translated by H. Konh. Fishing News (Book) Ltd. Farnhan surrey EnglandHenry M, Gasco L, Piccolo G, Fountoulaki E (2015). Review on 
the use of insects in the diet of farmed fish: Past and future. Animal feed technology, 203, 1-22

[36] Idowu, AS., Amusan, S. and Oyediran AG. (2003). The Response of Clarias gariepinus fingerlings (Burchell 1822) to the diet containing housefly maggot (Musca domestica) (L) Nig. J. Anim. Prod. 30(1):139 144 https://doi.org/10.4314/njap.v30i1.3325

[37] Jauncey K, (1982). A guide to Tilapia feeds and feeding, institute of Aquaculture, University of Syerling.

[38] Johannes Pucher1, Tuan Nguyen Ngoc, Trinh ThiHanhYen, Richard Mayrhofer, Mansour El-Matbouli, Ulfert Focken4 (2014). Earthworm Meal as Fishmeal Replacement in Plant based Feeds for Common Carp in Semi-intensive Aquaculture in Rural Northern Vietnam Turkish Journal of Fisheries and Aquatic Sciences 14: 557-565

[39] Komolafe OO, Arawomo GAO, (2008). Preliminary observations on fish Species in a newly impounded reservoir, Osinmo. Turkish Journal of Fisheries and Aquatic Sciences 8: 289-292.

[40] Mazid, M.A. Tennka, Y. Katayama, T. Ruhman, M.A. Simpson K.L. and Chichester, C.O. (1979). Growth response of Tilapia zilli fingerlings fed isocalaric diets in variable protein level. Aquaculture 18:115 - 122 https://doi.org/10.1016/0044-8486(79)90024-3

[41] Mustapha AK, (2001). An Investigation into the Value of Oven-dried Maggot as Protein Source in the Diet of Oreochromis niloticus Fingerlings. Journals of Pure and Applied Science. 3(1 and 2): 63 - 74.

[42] Nwadukkwe, FO. (1991). Brook stock Management and seed production. Proceeding of fish seed propagation course (Conducted by ARAL of NIOMR). Edited by A.O. Ayinla.

[43] Ng WK, Liew FL, Ang LP, Wong KW, (2001). Potential of mealworm (Tenebrio molitor) as an alternative protein source inpractical diets for African catfish, Clarias gariepinus. Aquaculture Res, 32: 273-280. https://doi.org/10.1046/j.1355-557x.2001.00024.x

[44] Ogunji J, Trua S, Schulz C, Kloas W, (2008). Growth performance, nutrient utilization of nile tilapia Oreochromis niloticus. Pak Vet J, 2014, 34(3): 288-292.

[45] Okayi RG, (2003). Effect of effluent discharge on water quality,distribution and abundance of plankton and fish species of RiverBenue. PhD Thesis. University of Ibadan.

[46] Olaleye VF, Akintunde E, (1991). Concentration and distribution of some mineral elements in the fille $t$ of Sarotherodon galilaeus (Artedi) in a Nigerian freshwater. $8^{\text {th }}$ Annual Conference of Fisheries Society of Nigeria (FISON) at Federal University of Technology, Akure

[47] Olaniyi CO, Salau BR, (2013). Utilization of maggot meal in the nutrition of African cat fish. African Journal of Agricultural Research. Vol. 8(37), pp. 4604-4607 https://doi.org/10.5897/AJAR12013.7154

[48] Olaleye, V.F. (1991): The effect of dietary protein quality growth and body composition of Sarotherodon ..lawus, Trewaves (Sin Tilapia calicles, Rated), fed on formulated diets. Ph.D. Thesis, Obafemi Awolowo University, Ile-Ife, Nigeria.

[49] Olvera - Novoa MA Campos, GS. Sabido, GM Martinez - Palacios CA. (1990) The use of alfalfa leaf protein concentrate as protein source in diets for tilapia (Oreochromis mossambicus). Aquaculture 90:291-302. https://doi.org/10.1016/0044-8486(90)90253-J

[50] Oyelese OA (2007). Utilization of compounded ration and maggot in the diet of Clarias gariepinus. Res J Appl Sci, 2: 301-306.

[51] Pullin, RSV. and Jhingran VG (1985): A hatchery Manual for the Common Vhinese and Indian major Carps Asia development bank ICLARM.

[52] Shang C Yung (1996). The role of Aquaculture in world Fisheries. In Heggberget. T.G. editor, 1996. The role of Aquaculture in world fishers, Proceeding of World Fisheries Congress. Theme 6: New Delhi ,Oxford and IBH Publishing Co. PVT.

[53] Silva JMG, Espe M, Conceição LEC, Dias J, Costas B, Valente LMP, (2010). Feed intake and growth performance of Senegalese sole(Solea senegalensis Kaup) fed diets with partialreplacement of fishmeal with plant proteins. Aquaculture Res, 41: e20-e30. https://doi.org/10.1111/j.1365-2109.2009.02451.x

[54] Sing KW, Kamarudin MS, Wilson JJ, Azirun MS, (2014). Evaluation of blowfly (Chrysomyamegacephala) maggot meal as an effective, sustainable replacement for fishmeal in the diet of farmed juvenile redtilapia (Oreochromis sp.). Pak Vet J, 34(3): 288-292.
[55] Spinelli, J, (1978). Unconventional feed ingredients for fish feeds. In Fish Feed Technology Aquaculture Development and Co-ordination Programme UNDF/FAO, $395 \mathrm{pp}$

[56] Teotia JS and Millar BF (1994) Nutritive of housefly pupae and manure residue Br Poultry Science 15:177-182 https://doi.org/10.1080/00071667408416093

[57] Vincent C. Ejere, Adetoun O. Adeniji, Chidinma A. Levi, Chinweike N. Asogwa and Christian O. Chukwuka(2014).Evaluation of Poultry Feather Meal as a Dietary Protein Source for Clarias gariepinus and Heterobranchus bidorsalis Hybrid . International Journal of Science and Technology Volume 3 No. 4 ,

[58] Watanabe WO, Losordo TM, Fitzsimmons K, Hanley F, (2002).Tilapia production systems in the Americas: Technologicaladvances, trends, and challenges. Rev Fish Sci, 103: 465-498. https://doi.org/10.1080/20026491051758

[59] Zuidhof MJ, Molnar CL, Morley FM, Wray TL, Robinson FE, Khan BA, Al-Ani L, Goonewardene LA, (2003). Nutritive value of house fly (Musca domestica) larvae as a feed supplement for turkey poults. Anim Feed Sci Tech, 105: 225-230

https://doi.org/10.1016/S0377-8401(03)00004-X 